\title{
ALTERNATIF HABITAT TEMPAT BERTELUR DAN MEDIA PERKEMBANGBIAKAN NYAMUK ANOPHELES
}

\section{(Alternative Habitat of Spawn place and Breeding Media for Anopheles Mosquito)}

\author{
Perdina Kadepa ${ }^{1}$ dan Beatrix I.S. Wanma ${ }^{1 凶}$ \\ Program Studi Biologi, Fakultas Sains dan Teknologi Universitas Ottow Geissler Papua. \\ Tlp/Fax: (0967)581562, 581133 \\ $\triangle$ Penulis Korespondensi: Email: beatrix.wanma@yahoo.com \\ Diterima: 06 Apr 2017| Disetujui: 22 Mei 2017
}

\begin{abstract}
Abstrak
Malaria adalah penyakit infeksi yang disebabkan oleh protozoa parasit yang merupakan golongan plasmodium yang hidup dan berkembang biak dalam sel darah merah manusia. Penyakit ini secara alami ditularkan melalui gigitan nyamuk Anopheles sp. Penelitian ini bertujuan untuk mengetahui alternatif habitat dan media perkembangbiakan yang sesuai bagi perkembangan jenis nyamuk Anopheles sp. Serta proses perkembangbiakannya. Hasil pengamatan telur Anopheles pada ketiga kondisi habitat dan media hidup terlihat bahwa jenis air limbah rumah tangga cenderung lebih tinggi yakni pada air kran sebanyak 279, sementara untuk media dan konsentrasi air sabun sebanyak 18 dan yang terkecil jumlahnya terdapat pada jenis media air lindi yakni tidak terjadi pertumbuhan dan peneluran nyamuk sama sekali (0).
\end{abstract}

Kata Kunci: Malaria, nyamuk Anopheles, air limbah, perkembangbiakan.

\begin{abstract}
Malaria was infectious disease caused by single-celled microorganisms of the plasmodium that live and bread inside humans red blood cells. The disease was naturally transmitted through Anopheles sp after being bitten by an infected mosquito. Thi research aimed to understand the alternative habitat as well as the suitable breeding media for the development of infected mosquito and its potential development. The result of eggs on the three habitat conditions growing media pointed out that household wastewater was likely higher in number in particular tap water with 279, while for 18 has been indicated in the media and soap water concentration. For the lowest number was found in waste water in which there was no indication of egg and Anopheles growth (zero).
\end{abstract}

Keywords: Malaria, Anopheles mosquito, waste water, breeding.

\begin{tabular}{|c|c|}
\hline PENDAHULUAN & (Aedes aegepyti) dan kaki gajah \\
\hline $\begin{array}{l}\text { Indonesia merupakan salah satu } \\
\text { negara tropis di dunia. Iklim tropis } \\
\text { menjadi penyebab berbagai penyakit } \\
\text { tropis yang disebabkan oleh nyamuk, } \\
\text { seperti malaria (Anopheles sp), filaria } \\
\text { (Wuchereria bancrofti), demam berdarah }\end{array}$ & $\begin{array}{l}\text { (filariasis), bahkan menimbulkan } \\
\text { epidemik atau kejadian penyakit yang } \\
\text { berlangsung dalam spektrum yang luas } \\
\text { dalam masyarakat (Kdarohman 2010). } \\
\text { Penyakit malaria merupakan masalah } \\
\text { kesehatan dan masyarakat di Indonesia, }\end{array}$ \\
\hline
\end{tabular}


angka kesakitan penyakit masih tinggi terutama kawasan indonesia di bagian timur. Penyakit ini sangat berpengaruh terhadap angka kesehatan masyarakat serta dapat menurunkan produktifitas kerja (Simpson 2009) yang disebabkan oleh infeksi protozoa dari genus Plasmodium dan ditularkan dari manusia ke manusia melalui gigitan nyamuk Anopheles betina (Luckman and Metcalf 1982). Nyamuk merupakan vektor penting dalam menyebabkan penyakit malaria (Govindarajang 2012). Beberapa vektor malaria yaitu Anopheles aconitus dan An. maculatus.An. aconitus aktif menggigit pada malam hari di rumahrumah penduduk. Tempat perindukan $A n$. aconitus terdapat di persawahan dan di irigasi. Nyamuk ini berkembang biak di daerah pegunungan dan perindukkan nyamuk ini terdapat di sungai kecil, mata air yang jernih dan tempat-tempat yang terkena sinar matahari langsung.

Angka kesakitan malaria di Propinsi Papua dalam kurung waktu 2005-2010 berkisar sebesar 193-223 per 1.000 penduduk (Nurdin 2007), ini merupakan tertinggi di Indonesia. Malaria dianggap sebagai penyebab kematian utama bagi semua kelompok umur di Papua walaupun data konkrit atau sebenarnya belum dapat diperoleh. Daerah endemik malaria, menyumbang angka kesakitan anemia dan kematian ibu hamil. Malaria menyebabkan ibu hamil melahirkan bayi dengan berat badan rendah, prematur dan menyebabkan kematian bayi. Akibat lainnya klien dalam usia produktif akan menurun produktifitasnya (Briand 2007). Proses perkembangbiakan nyamuk selalu memerlukan tiga macam tempat yaitu tempat berkembangbiak (breeding places), tempat untuk mendapat darah (feedingplaces), tempat untuk beristiraat (reesting places). Tempat berkembangbiak (breeding places) nyamuk Anopheles sp. bermacam-macam sesuai dengan jenisnya (Ernawati dkk. 2012). Berdasarkan penelitian yang dilakukan oleh Suwito dkk. (2010), di wilayah Kecamatan Rajabasa didapatkan 10 spesies Anopheles yang kontak dengan manusia yaitu An. Sundaicus, An. Vagus, An. Tessellatus, An. Aconitus, An. Subpicus, An. Annularis, An. Kochi, An. Minimus, An. Barbirostris dan An. Maculatus. Nyamuk Anopheles sundaicus merupakan spesies paling dominan ditunjukkan dari angka gigitan per jam.

Berdasarkan hal tersebut di atas maka penting dilakukan penelitian tentang pengujian 3 jenis air limbah rumah tangga yang mengandung air kran air sabun dan air lindi yang dipilih oleh nyamuk Anopheles sp. untuk meletekkan telurnya dan melihat perbandingan perkembangan telur dalam tiga wadah tersebut di Laboratorium Program Studi Biologi, Universitas Ottow dan Geisler Papua.

\section{METODE PENELITIAN}

Penelitian dilaksanakan selama sebuna pada Agustus 2016 di Laboratorium Biologi, Fakultas Sains dan Teknologi, Universitas Ottow \& Geissler Papua. Metode yang digunakan pada penelitian ini yaitu metode observasi secara langsung dengan teknik pengambilan sampel secara acak. Pengambilan sampel di lapangan terdiri dari 2 tahap yaitu: pengambilan sampel air dan sampel nyamuk Anopheles. Bahan utama sebagai media uji alternatif yang digunakan ialah air kran, air sabun (Lifebuoy $250 \mathrm{gr}$ ), dan air lindi. 


\section{Prosedur Kerja}

Prosedur kerja yang digunakan adalah sebagai berikut:

1. Menyediakan sangkar nyamuk sebanyak 3 buah, pada setiap sangkar diletakkan 3 wadah perangkap telur (ovitrap) yang masing-masing diisi air kran, air sabun (Lifebuoy, dengan konsentrasi 125 gr: 1 liter air) dan air lindi dengan volume 1 liter.

2. Pada setiap sangkar dimasukkan 40 ekor nyamuk

3. Untuk menghindari bias oleh karena adanya pengaruh cahaya dan suhu, diletakkan pada kamar yang sama sehingga setiap ovitrap akan memiliki kesempatan terpapar cahaya yang sama di dalam ruangan.

4. Jumlah telur yang ada di ovitrap dalam sangkar dihitung pada hari ke lima memakai kaca pembesar atau loup dan untuk konfirmasi atau lebih memudahkan dipakai mikroskop stereo.
5. Mengukur dan mencatat suhu dan $\mathrm{pH}$ konsentrasi air setiap hari dengan waktu : 09.00 (pagi), 12.00 (siang) dan 15.00 (sore).

\section{HASIL DAN PEMBAHASAN}

\section{Hasil}

Hasil yang didapat dari penelitian ini yaitu, jumlah daya tetas telur nyamuk Anopheles pada ovitrap, tiga air limbah rumah tangga yaitu air kran, air sabun (Lifebuoy) dan air lindi. Hasil tersebut dapat disajikan pada table 1. Pada Tabel 1, nyamuk Anopheles dapat bertelur di air kran dan air sabun, tetapi sama sekali tidak bertelur di air lindi. Hasil pengamatan jumlah tetas telur nyamukAnopheles selama 20 hari pada ketigaair limbah rumah tangga yaitu masing-masing air kran 1 liter (279), air sabun 1 liter (18) dan air lindi (0).

Tabel.1. Hasil Pengamatan Selama 20 Hari Daya Tetas Telur Pada Tiga Ovitrap Berisi AirLimbah Rumah Tangga

\begin{tabular}{|c|c|c|c|c|c|c|c|c|c|c|c|c|c|c|c|c|c|c|c|c|c|}
\hline \multirow[t]{2}{*}{ Sampel } & \multicolumn{20}{|c|}{ Hari } & \multirow[t]{2}{*}{$\sum$} \\
\hline & 1 & 2 & 3 & 4 & 5 & 6 & 7 & 8 & 9 & 10 & 11 & 12 & 13 & 14 & 15 & 16 & 17 & 18 & 19 & 20 & \\
\hline $\begin{array}{l}\text { Air Kran } \\
\text { (1 liter) }\end{array}$ & - & - & - & - & - & - & - & - & - & - & - & 27 & 30 & 0 & 130 & - & 92 & - & - & - & 279 \\
\hline $\begin{array}{l}\text { Air sabun } \\
\text { (1 liter) }\end{array}$ & - & - & 9 & - & 9 & - & - & - & - & - & - & - & - & - & & - & - & - & - & - & 18 \\
\hline $\begin{array}{l}\text { Air Lindi } \\
\text { (1 liter) }\end{array}$ & - & - & - & - & - & - & - & - & - & - & - & - & & - & - & - & - & - & - & - & 0 \\
\hline
\end{tabular}

Hasil pengukuran parameter $\mathrm{pH}$ dan suhu adalah pada air kran nilai $\mathrm{pH} 7,1$ netral, nilai $\mathrm{pH}$ pada konsentrasi air sabun 6,4 asam dan nilai $\mathrm{pH}$ pada konsentrasi air lindi 5,4 bersifat asam (Nalim 1975) sesuai dengan pengukuran suhu waktu pagi, siang dan sore nilai tidak berubah- ubah. Nilai suhu hasil pengukuran pada setiap waktu pengamatan pagi, siang dan sore selama waktu pengamatan tetap atau konstan yaitu masing-masing dengan nilai suhu: pagi $24^{\circ} \mathrm{C}$, siang $25^{\circ} \mathrm{C}$ dan sore $26^{\circ} \mathrm{C}$. 
Tabel 2. Hasil pengukuran parameter $\mathrm{pH}$ dan suhu konsentrasi air

\begin{tabular}{|c|c|c|c|c|c|c|c|c|}
\hline \multirow[t]{3}{*}{ No } & \multirow[t]{3}{*}{ Hari/Tgl/Thn } & \multirow[t]{3}{*}{ Waktu } & \multicolumn{6}{|c|}{ Sampel } \\
\hline & & & \multicolumn{2}{|c|}{ Air Kran } & \multicolumn{2}{|c|}{ Air sabun } & \multicolumn{2}{|c|}{ Air Lindi } \\
\hline & & & $\mathrm{pH}$ & suhu & $\mathrm{pH}$ & Suhu & $\mathrm{pH}$ & Suhu \\
\hline \multirow[t]{3}{*}{ 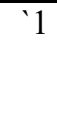 } & Senin, $22 / 08 / 16$ & 09.00 & 7,1 & $24^{\circ} \mathrm{C}$ & 6,4 & $24^{\circ} \mathrm{C}$ & 5,4 & $24{ }^{\circ} \mathrm{C}$ \\
\hline & & 12.00 & 7,1 & $25^{\circ} \mathrm{C}$ & 6,4 & $25^{\circ} \mathrm{C}$ & 5,4 & $25^{\circ} \mathrm{C}$ \\
\hline & & 15.00 & 7,1 & $26^{\circ} \mathrm{C}$ & 6,4 & $26^{\circ} \mathrm{C}$ & 5,4 & $26^{\circ} \mathrm{C}$ \\
\hline \multirow[t]{3}{*}{2} & Selasa, 23/08/16 & 09.00 & 7,1 & $24^{\circ} \mathrm{C}$ & 6,4 & $24^{\circ} \mathrm{C}$ & 5,4 & $24^{\circ} \mathrm{C}$ \\
\hline & & 12.00 & 7,1 & $25^{\circ} \mathrm{C}$ & 6,4 & $25^{\circ} \mathrm{C}$ & 5,4 & $25^{\circ} \mathrm{C}$ \\
\hline & & 15.00 & 7,1 & $26^{\circ} \mathrm{C}$ & 6,4 & $26^{\circ} \mathrm{C}$ & 5,4 & $26^{\circ} \mathrm{C}$ \\
\hline \multirow[t]{3}{*}{3} & Rabu 24/08/16 & 09.00 & 7,1 & $24^{\circ} \mathrm{C}$ & 6,4 & $24^{\circ} \mathrm{C}$ & 5,4 & $24^{\circ} \mathrm{C}$ \\
\hline & & 12.00 & 7,1 & $25^{\circ} \mathrm{C}$ & 6,4 & $25^{\circ} \mathrm{C}$ & 5,4 & $24^{\circ} \mathrm{C}$ \\
\hline & & 15.00 & 7,1 & $26^{\circ} \mathrm{C}$ & 6,4 & $26^{\circ} \mathrm{C}$ & 5,4 & $25^{\circ} \mathrm{C}$ \\
\hline \multirow[t]{3}{*}{4} & Kamis, 25/08/16 & 09.00 & 7,1 & $24^{\circ} \mathrm{C}$ & 6,4 & $24^{\circ} \mathrm{C}$ & 5,4 & $26^{\circ} \mathrm{C}$ \\
\hline & & 12.00 & 7,1 & $25^{\circ} \mathrm{C}$ & 6,4 & $25^{\circ} \mathrm{C}$ & 5,4 & $24^{\circ} \mathrm{C}$ \\
\hline & & 15.00 & 7,1 & $26^{\circ} \mathrm{C}$ & 6,4 & $26^{\circ} \mathrm{C}$ & 5,4 & $25^{\circ} \mathrm{C}$ \\
\hline \multirow[t]{3}{*}{5} & Jumat, 26/08/16 & 09.00 & 7,1 & $24^{\circ} \mathrm{C}$ & 6,4 & $24^{\circ} \mathrm{C}$ & 5,4 & $26^{\circ} \mathrm{C}$ \\
\hline & & 12.00 & 7,1 & $25^{\circ} \mathrm{C}$ & 6,4 & $25^{\circ} \mathrm{C}$ & 5,4 & $24^{\circ} \mathrm{C}$ \\
\hline & & 15.00 & 7,1 & $26^{\circ} \mathrm{C}$ & 6,4 & $26^{\circ} \mathrm{C}$ & 5,4 & $24^{\circ} \mathrm{C}$ \\
\hline
\end{tabular}

\section{PEMBAHASAN}

Air limbah merupakan sisa dari suatu usaha atau kegiatan yang terwujud cair [PP RI Nomor 82 tahun 2001, Bab 1 Pasal 1 Butir (14)] menurut (Azwar 1983) yang dimaksud dengan air limbah atau air kotor ialah air yang tidak bersih dan mengandung mineral yang bersifat membahayakan kehidupan mahkluk hidup dan lazimnya muncul karena hasil perbuatan manusia termasuk industri. Berdasarkan hasil penelitian pada tiga sangkar nyamuk yang berisi air limbah rumah tangga yakni air kran, air sabun, dan air lindi, hasil yang diperoleh baik itu peletakan jumlah telur dan pengukuran parameter $\mathrm{pH}$ dan suhu sangat berbeda.

\section{Air kran}

Pengamatan pada ovitrap air kran 1 liter, selama 16 hari pengamatan sama sekali tidak dijumpai telur. Pada hari pengamatan 12, 13 dan 15 dijumpai telur dengan masing-masing jumlah 27, 30, dan 130 butir telur Anopheles, total butir telur yang didapatkan adalah 187 butir telur. Sedangkan pada hari pengamatan 11 dan 14 sama sekali tidak dijumpai telur. Kemudian pada hari ke- 17 dijumpai 92 butir telur, sehingga jumlah total telur menjadi 279 telur. Pada hari pengamatan 16, 18, 19 dan 20 sama sekali tidak ditemui telur Anopheles tetapi 1 ekor mati pada pengamatan hari ke- 16 , hal ini sangat dipengaruhi oleh suhu dan $\mathrm{pH}$. Hasil pengukuran suhu dan $\mathrm{pH}$ di dalam air kran ialah $\mathrm{pH} 7,1$ (netral) dengan rata-rata nilai suhu $24-26^{\circ} \mathrm{C}$. Nalim (1975) menyatakan bahwa, suhu sangat mempengaruhi pertumbuhan larva nyamuk dan mortalitas larva yang terendah adalah pada suhu $25-26^{\circ} \mathrm{C}$. Suhu air mempengarui secara langsung toksisitas bahkan kimia tercemar, pertumbuhan mikroorgansme dan virus (Kristanto 2002).

Salah satu faktor lingkungan yang mempengaruhi pertumbuhan atau perkembangan mikroorganisme dalam air adalah derajat keasaman $(\mathrm{pH})$. Hasil pengukuran $\mathrm{pH}$ pada air kran menunjukkan nilai $\mathrm{pH} 7,1$ netral dan tidak terjadi perbedaan nilai $\mathrm{pH}$ selama 
20 hari pengamatan. Nilai $\mathrm{pH}$ tersebut merupakan nilai $\mathrm{pH}$ yang masih dapat ditoleransi untuk hidup oleh Anopheles karena banyak nyamuk yang dapat bertahan hidup pada kisaran $\mathrm{pH} 7$ yang merupakan $\mathrm{pH}$ optimum pertumbuhan nyamuk (Permono 1985). Kondisi lingkungan dapat mempengaruhi kandungan air dalam larva, sehingga keaktifan larva terganggu. Daya adaptasi larva terhadap lingkungan (asam - basa) lemah sehingga responnya pun akan berbeda-beda. Respon larva terhadap lingkungan mempengaruhi perkembangan dan pertumbuhannya

\section{Air Sabun}

Konsentrasi air sabun 1 liter, pada hari pengamatan 3 dan 5 djumpai telur Anopheles dengan jumlah masing-masing yaitu 9 dan 9 butir telur, ditambah menjadi 18 telur, sedangkan hari pengamatan ke - 1, 2, 4 hingga 5-20 tidak dijumpai telur. Sesuai dengan pengamatan selama dua puluh hari dijumpai nyamuk Anopheles mati, pada hari ke - 6 dijumpai 4 ekor dan pada hari ke- 15 menjumpai 8 ekor. Nilai parameter $\mathrm{pH}$ dan suhu rata-rata pada konsentrasi air sabun ialah: nilai $\mathrm{pH} 6,4$ asam dan nilai suhu 24 - $26^{\circ}$ C. Anopheles mampu menetaskan telurnya namun tidak dapat bertahan dan tumbuh pada perindukan air sabun. Hasil menunjukkan bahwa Anopheles hanya mampu bertahan selama 5 hari, pada hari ke - 6 nyamuk Anopheles langsung mengalami kematian 100\% hingga sampai hari ke - 15. Proses pertumbuhan Anopheles tidak terjadi pada penelitian ini dikarenakan Anopheles bertahan hidup selama lima hari saja. Suhu air mempengarui secara langsung toksisitas bahkan kimia tercemar, pertumbuhan mikroorgansme dan virus (Kristanto 2002).

Anopheles tidak dapat bertahan dalam kondisi yang relatif banyak mengandung bahan-bahan kimia. Larutan sabun beraksi basa karena terjadi hidrolisis sebagian serta mempunyai sifat membersihkan karena dapat mengemulsikan kotoran yang melekat pada badan (Wardhana 1995). Sabun berasal dari asam lemak yaitu stearat, palmitat atau aleat yang terbentuk dari reaksi kimia.

Anopheles yang mati dalam media yang banyak mengandung sabun disebabkan karena Anopheles tidak dapat bertahan dengan kondisi media yang lama kelamaan bersifat zat adiktif yaitu obat serta bahan - bahan yang apabilah dikomsumsi oleh organisme hidup maka dapat menyebabkan kerja biologi serta menimbulkan ketergantungan yang sulit dihentikan. Anopheles yang mati ditandai dengan tubuh bengkok dan bagian tubuh terlihat berwarna hijau sama seperti endapan yang ada. Emulsi yang terjadi pada kotoran oleh sabun ditandai dengan terbentuknya misel adalah molekul molekul surfaktan yang mulai berasosiasi karena penambahan sulfaktan berikutnya. Larutan sabun tampak berubah warna akibat sifat-sifat penghambat cahaya misel yang terbentuk dari anion asam lemak yang membentuk lemak sabun.

Daya pembersih sabun bertumpu pada sifat amfipatikartinya banyak lipida yang mempunyai sifat fisik molekul sabun. Prosesnya dimulai dari material berlemak yang menahan kotoran dihancurkan oleh molekul - molekul sabun pada permukaan dengan mengikatkan diri pada molekul - molekul lemak. Bagian-bagian polar dari molekul - molekul sabun yang bergabung menyebabkan kotoran dan 
partikel lemak mantap dalam larutan berair sehingga dapat dicuci lepas di dalam air. Endapan yang terjadi kemungkinan lepasnya karena partikel partikel lemak beserta kotoran di dalam air karena pengaruh lamanya waktu pengamatan pada ovitrap yang berisi air lindi 1 liter, pengamatan yang berlangsung selama 20 hari, baik pengamatan pada hari pertama sampai dengan hari ke dua puluh, sama sekali tidak dijumpai telur Anopheles. Pengamatan pada hari ke - 6 terdapat 1 ekor mati sedangkan pada hari ke - 15 dijumpai sebanyak 2 ekor. Nilai parameter suhu dan $\mathrm{pH}$ pada konsentrasi air lindi ialah nilai $\mathrm{pH}$ 2,5 kemudian nilai suhu berkisar antara $24-26^{\circ} \mathrm{C}$. Kemampuan air untuk mengikat atau melepaskan sejumlah ion hidrogen akan menunjukan apakah perairan tersebut bersifat asam atau basa. Selanjutnya peneliti menambahkan bahwa nilai $\mathrm{pH}$ perairan dapat berfluktuasi karena dipengaruhi oleh aktivitas fotosintesis, respirasi organisme akuatik, suhu dan keberadaan ion-ion di perairan tersebut. Air lindi pada umumnya mengandung senyawa - senyawa organik antara lain: hirdokarbon dan sulfat, kemudian anorganik yaitu natrium, kalium, kalsium, magnesium, khlor, sulfat, fosfat, fenol, nitrogen dan senyawa logam berat yang tinggi. Konsentrasi dari komponenkomponen tersebut dalam air lindi bisa mencapai 1000 sampai 5000 kali lebih tinggi dari pada konsentrasi dalam air tanah (Maramis 2008).

Potensi tetas telur telur Anopheles yang paling banyak di jumpai selama 20 hari pengamatan pada ketiga ovitrap atau perangkap telur yang berisi air limbah rumah tangga ialah pada air kran dengan jumlah rata-rata adalah 279 butir telur, kemudian pada konsentrasi air sabun berjumlah 18 butir telur lalu pada air lindi sama sekali tidak dijumpai telur Anopheles. Hal ini sangat dipengaruhi oleh $\mathrm{pH}$ dan suhu, sesuai dengan hasil pengukuran parameter $\mathrm{pH}$ dan suhu selama pengamatan berlangsung baik pada pagi, siang dan sore hari. Nilai ratarata suhu pada air kran 1 liter, konsentrasi air sabun 1 liter dan konsentrasi air lindi 1 liter pada pagi berkisar $24^{\circ} \mathrm{C}$ pengamatan berlangsung selama 20 hari. Pada siang hari nilai suhu naik $25^{\circ} \mathrm{C}$ kemudian hasil pengukuran nilai suhu pada sore hari lebih tnggi naik menjadi $26^{\circ} \mathrm{C}$ pada masing-masing ketiga air limbah rumah tangga tersebut. Pengukuran dilaksanakan pada waktu yang sama maka nilai suhu pada ketiga konsentrasi air limbah rumah tangga sama, tetapi pengukuran suhu pada waktu yang berbeda maka nilai suhu juga otomatis berubah. Nalim (1975) menyatakan bahwa, suhu mempengaruhi perkembangan larva nyamuk dan mortalitas larva yang terendah adalah pada suhu $25-26^{\circ} \mathrm{C}$. Disamping itu, suhu air mempengaruhi secara langsung toksisitas bahan kimia pencemar pertumbuhan mikroorganisme dan virus (Kristanto 2002).

Kualitas air bagi kehidupan larva pada umumnya ditentukan oleh sifat fsika, kimia dan biologi perairan yang relevan bagi kehidupan bagi kehidupan jasadjasad perairan, bahan-bahan yang terlarut dan mengalami perombakan menentukan sifat kimia perairan tersebut. Faktor lingkungan yang berpengaruh terhadap daur hidup adalah suhu, sedangkan Chandler and Reads (1961) menyebutkan bahwa perkembangan larva bergantung pada jenis nyamuk dan penyediaan makanan. Larva yang hidup di dalam air yang bersuhu relatif tinggi akan 
mengalami kenaikan kecepatan respirasi serta menurunkan jumlah oksigen terlarut di dalam air, sehingga mengakibatkan larva akan mati karena kurang oksigen. Oksigen terlarut dalam air berasal dari udara yang secara lambat terdifusi kedalam air. Makin tinggi kenaikan suhu air, makin sedikit oksigen yang terlarut didalamnya. Suhu air limbah yang relatif tinggi ditandai antara lain dengan munculnya hewan - hewan air ke permukaan untuk mencari oksigen (Wordhana 1995; Kristanto 2002). Suhu suatu badan perairan dipengaruhi oleh musim, posisi lintang, ketinggian dan permukaan laut, waktu dalam hari, silkulasi udara, penutupan awan, dan aliran serta kedalaman badan air. Perubahan suhu dipengaruhi terhadap proses fisika, kimia dan biologibadan air (Effendi 2003).

Peningkatan suhu dapat mengakibatkan viskositas, reaksi kimia, evavorasi dan volatilisasi. Peningkatan suhu juga dapat menyebabkan penurunan larutan gas dalam air, seperti oksigen $\left(\mathrm{O}_{2}\right)$, karbondioksida $\left(\mathrm{CO}_{2}\right)$ dan natrium $\left(\mathrm{N}_{2}\right)$ sebagainya (Effendi 2003). Salah satu faktor yang dapat mempengaruhi pertumbuhan atau kehidupan mikroorganusme dalam air adalah derajat keasaman $(\mathrm{pH})$ yaitu insensitas atau basa sesuatu larutan dalam air. Hasil pengukuran $\mathrm{pH}$ pada limbah menunjukkan perbedaan antara tiga ovitrap berisi air kran, air sabun dan air lindi. Derajat keasaman tertinggi rata-tara 7 netral, sedangkan $\mathrm{pH}$ terendah 5,4. Nilai $\mathrm{pH}$ tersebut merupakan nilai yang masih dapat toleransi oleh larva Anopheles karena banyak larva yang hidup pada kisaran $\mathrm{pH} 7$ yang merupakan $\mathrm{pH}$ optimum pertumbuhan larva Anopheles. Menurut penelitian Permono (1985) larva
Cx. quinguefasciatus say. Mempunyai kemampuan hidup pada tinggi $\mathrm{pH} 7$ antara suhu yang berbeda dan pada $\mathrm{pH} 6$ dengan suhu $26^{\circ}$ C. Kebanyakan mikroorganisme merupakan makanan larva, pertumbuhan optimalnya pada $\mathrm{pH}$ 6,0 sampai 8 sedangkan pada beberapa jenis organisme pada $\mathrm{pH}$ kurang atau lebih kisaran tersebut. Larva $C x$. quinguefasciatus. tidak tahan terhadap $\mathrm{pH}$ 2,0 (Daly et al. 1981).

\section{DAFTAR PUSTAKA}

Aswar A. 1983. Pengantar ilmu kesehatan lingkungan. Jakarta: Mutiara. Balai Laboratorium. 2000. Makalah, Semarang.

Briand. 2007. Intermittent preventive treatment for the prevention of malaria during pregnancy in high transmission areas. Malaria Jurnal.

Chandler AC and Reads PC. 1961. Introduction to parasitology with special reference to the parasites of man. $10^{\text {th }}$ edition. John Wiley and Sons Incorporated, New York. 822pp.

Daly HV, John T, Doyen and Paul RE. 1981. Introduction to insect biolgy and diversity. International Student edition. Japan: Mc Grow-Hill, Inc.

Effendi H. 2003. Telaah kualitas air bagi pengolaan sumberdaya dan lingkungan perairan. Kanisius Yogjakarta.

Ernawati K, Achmadi U, Soemardi T, Thayyib H, Mutia S. 2012. Tambak terlantar sebagai tempat perindukan nyamuk di daerah endemis malaria. Penyebab dan penanganannya. Jurnal Ilmu Lingkungan [Internet]. [disitasi 10 November 2014].

Govindarajang. 2012. Hubungan faktor lingkungan fisik rumah dengan 
kejadian penyakit malaria di Desa Suka Karya Kecamatan Simeulue Timur Kabupaten Simeulue Provinsi Aceh. Skripsi Universitas Sumatera Utara. Medan.

Kdarohman 2010. Malaria di indonesia tinjauan aspek epidemiologi. Makasar: Masagena Press.

Kristanto P. 2002. Ekologi industri. Yogyakarta: Penerbit Andi Offset.

Luckman WH and Metcalf RL. 1982. The pest management concept, In Luckman \& Metcalf (eds), "Introduction to insect pest management. John Wiley \& Son. New York.

Maramis A. 2008. Pengolaan sampah dan turunannya di TPA. Alumni Program Pasca Sarjana Magister Biologi Terapan. Salatiga: Universitas Satyawacana.

Nalim S. 1989. Pendekatan secara terpadu untuk memberantas vektor. Makalah
Diskusi Ilmiah Balitbang Kes. Jakarta 19 Maret 1989.

Nurdin E. 2007. Faktor-faktor resiko yang mempengaruhi kejadian malaria. Studi kasus di wilayah kerja Puskesmas Hamadi Kota Jayapura. Tesis. Universitas di Ponegoro. Semarang.

Permono IN. 1985. Pengaruh temperatur, kekeruhan air dan $\mathrm{pH}$ terhadap perkembangan larva culex quinguefasciatus. Makalah Seminar.

Simpson 2009. Program penanggulangan malaria di Provinsi Sumatra Utara. Medan.

Suwito, Hadi U, Sigit S, Sukawati S. 2010. Hubungan iklim, kepadatan nyamuk Anopheles dan Kejadian Penyakit Malaria. Jurnal Entomologi Indonesia.[Internet]. [disitasi 10 November 2014).

Wardhana WA. 1995. Dampak pencemaran lingkungan. Jogyakarta : Penerbit Andi Offset. 